\title{
Evaluation of Hormone Receptors Status in Breast Carcinoma
}

\author{
Begum KNA ${ }^{1}$, Akond AK ${ }^{2}$, Huq N ${ }^{3}$, Aymon NN ${ }^{4}$, Huq F ${ }^{5}$
}

Conflict of Interest: None

Received: $04-03-2018$

Accepted: $16-10-2018$

www.banglajol.info/index.php/JSSMC

Key Words: Breast cancer, hormone receptor status, $E R, P R$, Her2/neu status etc.

\begin{abstract}
Background \& objective: The importance of establishing hormone receptor status of tumors for the treatment of women with hormone receptor-positive breast cancer is often emphasized. It is critical to evaluate hormone receptor status when considering response to endocrine therapy. The present study was intended to evaluate the usefulness of hormone receptor status in breast carcinoma.
\end{abstract}

Materials \& Methods: The present study was conducted in the Department of Pathology, Dhaka Medical College, Dhaka over a period 12 months from July 2009 to June 2010. A total of 30 histopathologically diagnosed cases of breast tumors who were also subjected to immunohistochemical (IHC) test for ER, PR status and HER-2/neu were consecutively included in the study. Patients who have already been treated for malignancy or who had a history of receiving radiotherapy were excluded.

Result: Age distributions shows that 40\% of the patients were early middle-aged (30-40 years), $30 \%$ middle-aged and the rest were either $<30$ years or $>50$ years old. Left breast was involved more often (56.7\%) than the right breast (43.3\%). The predominant location was upper outer quadrant (43.3\%), followed by upper inner quadrant (20\%), lower outer quadrant $(20 \%)$, lower inner quadrant (10\%) and central (6.7\%). Over half (53.3\%) of the tumors were $<5 \mathrm{~cm}$ and the rest $5 \mathrm{~cm}$ or more. Nearly half $(46.7 \%)$ of the tumors were moderately differentiated, $36.6 \%$ well-differentiated and $16.7 \%$ poorly differentiated. In majority (83.3\%) of the cases lymph-nodes (axillary lymph nodes) were involved. Based on estrogen and progesterone receptor status, over half (53.3\%) of the tumors were ER and PR positive and $40 \%$ were Her2/neu overexpressed.

Conclusion: The study concluded that half of the Bangladeshi breast cancer patients are ER and $P R$ positive and two in every five cases are Her2/neu overexpressed.

[J Shaheed Suhrawardy Med Coll 2018; 10(2): 70-73] DOI: https://doi.org/10.3329/jssmc.v10i2.41160

\section{Introduction:}

Breast cancer is the most common cancer worldwide. It is the second major cause of cancer deaths among women in the United States. ${ }^{1}$ According GLOBOCAN estimates, more than half $(52.9 \%)$ of the 1.67 million new breast cancer cases were diagnosed in developing countries in $2012 .^{1}$

1. Dr. Kazi Nishat Ara Begum, Associate Professor, Department of Pathology, Shaheed Suhrawardy Medical College, Dhaka

2. Professor (Dr.) Abdul Khaleque Akond, Ex Head, Department of Pathology, Dhaka Medical College, Dhaka.

3. Dr. Naila Huq, Associate Professor, Department of Pathology, National Institute of Neurosciences, Dhaka

4. Dr. Nazneen Naher Aymon, Assistant Professor, Department of Pathology, Sir Salimullah Medical College, Dhaka.

5. Dr. Fahmida Huq, Assistant Professor, Department of Pathology, Shaheed Suhrawardy Medical College, Dhaka

Correspondence to: Dr. Kazi Nishat Ara Begum, Associate Professor, Department of Pathology, Shaheed Suhrawardy Medical College, Dhaka, Mobile: +8801795362641 E-mail: knab63@gmail.com
South Asia, the home of approximately 588 million women over 15 years of age, ${ }^{2}$ facing a growing breast cancer epidemic as the incidence of breast cancer is increasing dramatically. ${ }^{3}$ Although Bangladesh has made enormous progress in the health sector, especially related to infectious diseases, ${ }^{4}$ the issue of cancer is given less priority at both policy and research level. ${ }^{5}$ Not much information on breast cancer in Bangladesh is available. According to National Institute of Cancer Research and Hospital report, 5255 breast cancer cases were diagnosed during the period 2005-2010. Providing quality care to these huge number cancer cases is really a challenge.

In the last two decades the treatment of breast cancer has changed a lot. For better prediction of a patient's response to endocrine therapy and their prognosis, biological markers hormone receptor status is now essential. The estrogen receptor (ER), progesterone receptor (PR), and 
proto-oncogene HER2/neu (HER2) profile of a female primary breast carcinoma plays a significant role as a predictive marker in patient management. Current therapeutic strategies for management of primary breast carcinomas rely on the accurate immunohistochemical (IHC) determination of hormone receptor status in order to determine the clinical utility of hormone-directed therapies such as selective estrogen receptor modulators (SERMs). For example, multiple major clinical trials conducted by the National Surgical Adjuvant Breast and Bowel Project have shown that addition of Tamoxifen, a SERM, to conventional chemotherapeutic and surgical treatment protocols consistently improves disease free survival in women with hormone receptor-positive tumors. ${ }^{6}$

Patients with tumors that are diagnosed with positive ER and/or PR status have lower risks of mortality compared to women with negative ER and/or PR disease. ${ }^{7-11}$ Clinical trials have also demonstrated that the survival advantage for women with hormone receptor-positive tumors is increased by treatment with adjuvant hormonal and/or chemotherapeutic regimens. ${ }^{12}$ HER2-neu, which encodes a receptor tyrosine kinase, is amplified and over-expressed in $20-25 \%$ breast cancers and such tumors are often resistant to hormone therapy. ${ }^{13}$

However, data on breast cancer markers including ER, PR and Her2/neo expression are scarce. None of the public hospitals except NICRH have the marker testing facilities in general. Only three private clinics/hospitals offer breast cancer marker testing services, mainly for affluent people (BSMMU). A retrospective study on 1042 breast cancer cases demonstrated that $69 \%$ and $73 \%$ of the cases were $\mathrm{ER}^{+}$and $\mathrm{PR}^{+}$respectively. About $28 \%$ of cases showed Her $2 /$ neu overexpression and $9 \%$ had triple negative breast cancer (TNBC). ${ }^{14}$ However, no special attention has been given on hormone receptor status of breast cancer in the Public Health Sector of Bangladesh. The present study was, therefore, designed to evaluate the biological markers that are commonly assessed with breast cancer to predict a patient's response to endocrine therapy and their prognosis for better clinical outcomes.

\section{Patients and Methods:}

This cross-sectional study was conducted in the Department of Pathology, Dhaka Medical College, Dhaka over a period 12 months July 2009 to June 2010. A total of 30 histopathologically diagnosed cases of breast tumors who were also subjected to immunohistochemical (IHC) test for ER, PR and HER-2/neu status were consecutively included in the study. The goal of determining the receptor status is not only to predict prognosis but also to decide its treatment (that is providing right treatment to the right patient). This hormone receptor status is graded using Allred ${ }^{15}$ scoring and grading system. Depending on the hormone status, breast carcinomas were divided into a number of different categories ranging from ER, PR, HER2/ neu positive and triple positive through triple negative.

The data were collected on a structured questionnaire containing the variables of interest. patients having primary ductal and lobular breast carcinoma were evaluated for their receptor status. The pathology reports were reviewed for patient's demographics, side of breast involved, location and size of tumor, lymph node involvement, histological grade and differentiation of carcinoma according to World Health Organization (WHO) classification of breast tumours ${ }^{16}$.

\section{Result:}

Age distributions shows that $40 \%$ of the patients were early middle-aged ( $30-40$ years), 30\% middle-aged and the rest were either $<30$ years or $>50$ years old. Left breast was involved more often $(56.7 \%)$ than the right breast (43.3\%). The predominant location was upper outer quadrant (43.3\%), followed by upper inner quadrant (20\%), lower outer quadrant $(20 \%)$, lower inner quadrant (10\%) and central $(6.7 \%)$. Over half $(53.3 \%)$ of the tumors were $<$ $5 \mathrm{~cm}$ and the rest $5 \mathrm{~cm}$ or more (Table I). Nearly half(46.7\%) of the tumors were moderately differentiated, $36.6 \%$ welldifferentiated and $16.7 \%$ poorly differentiated (Table II). In majority $(83.3 \%)$ of the cases lymph-nodes were involved. In terms of receptor status, more than half (53.3\%) of the tumors were ER and PR positive and 40\% were Her $2 /$ neu overexpressed (Table III).

Table I

Distribution of patients by their demographic and clinical features $(n=30)$

Clinical characteristics $\quad$ Frequency Percentage

Age (years)

$\begin{array}{lll}<30 & 2 & 6.7\end{array}$

$30-40$

$12 \quad 40.0$

$40-50$

$9 \quad 30.0$

$>50$

7

23.3

Breast involved

Right

$13 \quad 43.3$

Left

17

56.7

Location of tumor

$\begin{array}{lll}\text { UOQ } & 13 & 43.3\end{array}$

$\begin{array}{lll}\text { UIQ } & 6 & 20.0\end{array}$

$\begin{array}{lll}\text { LIQ } & 3 & 10.0\end{array}$

$\begin{array}{lll}\text { LOQ } & 6 & 20.0\end{array}$

Central

$2 \quad 6.7$

Size of Tumor $(\mathrm{cm})$

$<5 \quad 16 \quad 53.3$

$\geq 5 \quad 14 \quad 46.7$

$*$ Mean age $=(42.9 \pm 9.9)$ years; range $=(25-71)$ years. 


\section{Table II}

Distribution of patients by findings of histopathology $(n=30)$

\begin{tabular}{lcc} 
Results of histopathology & Frequency & Percentage \\
\hline Differentiation & & \\
Well & 11 & 36.6 \\
Moderate & 14 & 46.7 \\
Poor & 5 & 16.7 \\
Lymph-node involvement & 25 & 83.3 \\
\hline
\end{tabular}

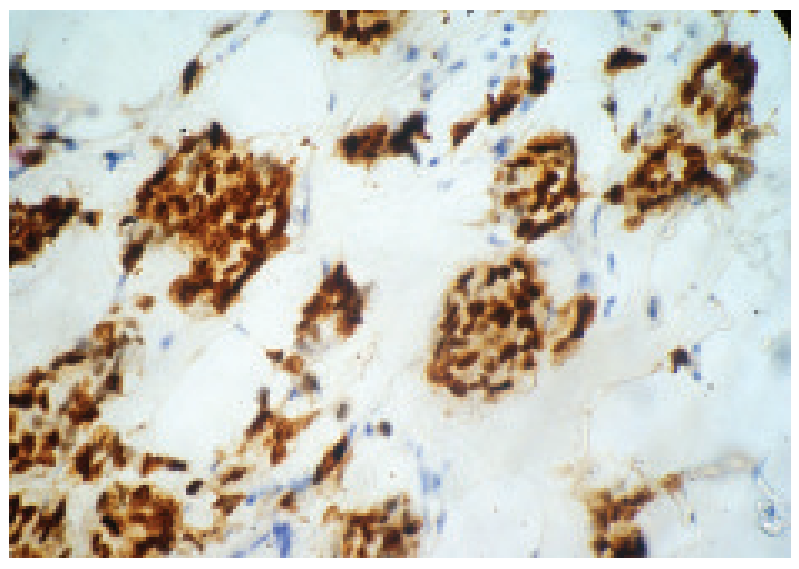

Fig.1: Photomicrograph showing nuclear immunoreactivity for Estrogen receptor in invasive ductal carcinoma by Immuno-staining.

\section{Table-III}

Distribution of patients by ER, $P R$ and HER2 receptor status $(n=30)$

Receptor status $\quad$ Frequency $\quad$ Percentage

ER

$+\mathrm{ve}(\mathrm{e}$ "3)

16

53.3

- ve $(0-2)$

14

46.7

PR

$+\mathrm{ve}(\mathrm{e} " 3)$

16

53.3

- ve $(0-2)$

14

46.7

HER2

$+\mathrm{ve}(2+-3+)$

12

40.0

- ve $(0-1+)$

18

60.0

TNBC

4

13.3

\section{Discussions:}

In the present study over half $(53.3 \%)$ of the breast carcinoma cases were positive for estrogen and

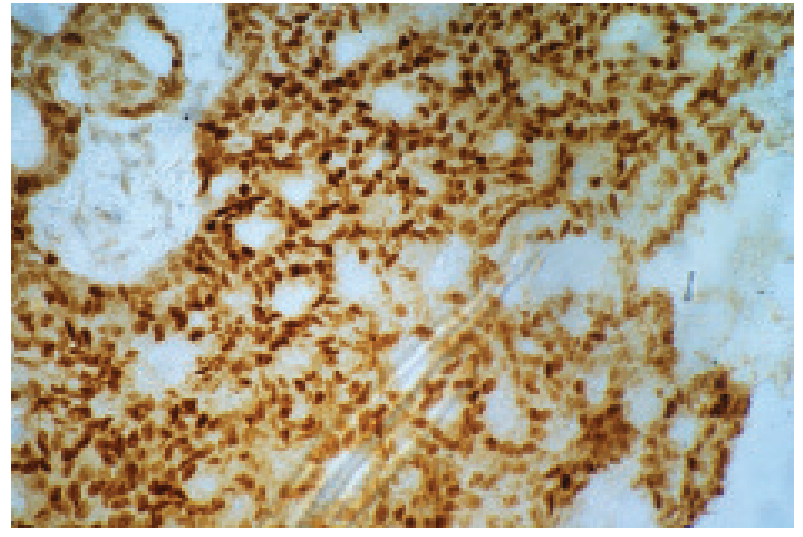

Fig.-2: Photomicrograph showing nuclear immunoreactivity for Progesterone receptor in invasive ductal carcinoma by immuno-staining.

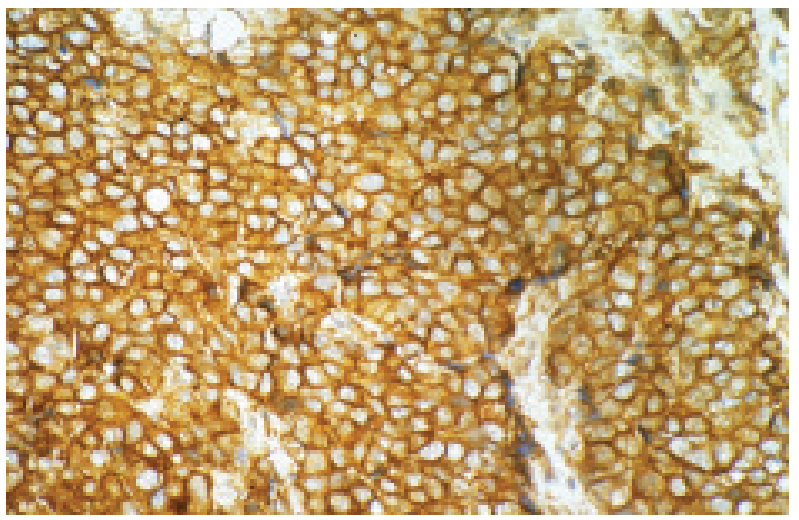

Fig. 3: Fig.-2: Photomicrograph showing membrane immunoreactivity for HER2/neu receptor in invasive ductal carcinoma by immuno-staining.

progesterone receptor (ER) status. A recent clinical trial conducted by the International Breast Cancer Foundation (IBCRF) demonstrated that $72 \%$ of breast cancers were ER-positive. ${ }^{17}$ Nadji and associates ${ }^{18}$ reported positive nuclear staining for ER and PR in 75 and $55 \%$ of invasive carcinomas respectively. The wide difference in the ER status between their findings and the findings of the present study might be that these tests were conducted on 30 cases only, while Nadji and associates conducted these tests on 5,993 cases of breast cancer. In neighboring state of India (West Bengal), about $57 \%$ of breast cancer patients were ER- positive, while $22 \%$ of the cases were triple-negative. ${ }^{19}$ The presence of estrogen and progesterone receptors in breast carcinomas has long been known to be of significance in evaluating long-term prognosis and therapeutic strategies. The status of breast cancer hormone receptors/molecular subtypes may be influenced by race, age, grade and stage. ${ }^{20-22}$ In general, the ER-positive rates in Western countries are around 70\% compared with $60 \%$ in Asia. ${ }^{23}$

In the present study human epidermal growth factor receptor-2 (HER2) was found to be overexpressed in $40 \%$ 
of the cases of breast carcinoma. Pevlic et al (1992) observed overexpression of HER 2 protein in approximately $25-30 \%$ of breast carcinoma which is somewhat lower than the findings of the present study. The breast cancers with overexpression of HER2 bears poor prognosis. Of the 30 cases, $4(13.3 \%)$ were triple negative. The risk of TNBC is three times greater in women of African origin. ${ }^{21}$ Triple negative breast cancer (TNBC) is a newly proposed sub-type of breast cancer with poor biological behaviors, high invasiveness and poor prognosis. It cannot benefit from endocrine therapy and HER2 targeted therapy due to the negative ER, negative progesterone receptor PR and negative HER $2^{24}$ and chemotherapy is, therefore, the drug of choice for such tumors. Among South Asians/ Bangladeshis in the UK and US, the proportion of hormonereceptor-negative breast cancer is higher than in Caucasians. The prevalence of TNBC was found to be the second highest in South Asians (19\%) after Black women $(25 \%) .{ }^{20,22}$ All these data suggest that the hormone receptor status of the Bangladeshi breast cancer population is not vastly different from that in high-income countries.

\section{Conclusion:}

The study concluded that half of the Bangladeshi breast cancer patients are ER and PR positive and two in every five cases are Her2/neu overexpressed. However, as the sample size was small, the findings should be interpreted with caution.

\section{References:}

1. Ferlay J, Soerjomataram I, Ervik M, Dikshit R, Eser S, Mathers C, et al. GLOBOCAN 2012 v1.0, Cancer incidence and Mortality Worldwide: IARC Cancer-Base No. 11. Lyon, France: International Agency for Research on Cancer, 2014, Available from: http://globocaniarcfr, accessed on 07.07.14.

2. CIA The World Factbook; 2014, http://wwwciagov/library/ publications/the-world-factbook/geos/bghtml.

3. Shetty P. India faces growing breast cancer epidemic. Lancet 2012;379:992-3.

4. Das P, Horton R. Bangladesh: Innovating for health. Lancet 2013;382:1681-2.

5. Hussain SA, Sullivan R. Cancer control in Bangladesh. Jpn J Clin Oncol 2013;43:1159-69.

6. Mamounas EP. NSABP breast cancer clinical trials: recent results and future directions. Clin Med Res 2003;4:309-326.

7. Henderson BE, Ross RK, Pike MC, Casagrande JT. Endogenous hormones as a major factor in human cancer. Cancer Res 1982;42:3232-9.

8. Key TJ, Pike MC. The role of estrogens and progesterone in the epidemiology and prevention of breast cancer. Eur J Cancer Clin Oncol 1988;24:29-43.
9. Ferguson DJ, Anderson TJ. Morphological evaluation of cell turnover in relation to the menstrual cycle in the "resting" human breast. Br J Cancer 1981;44:177-81.

10. Henderson BE, Ross RK, Pike MC. Hormonal chemoprevention of cancer in women. Science 1993;259:633-8.

11. Fisher B, Redmond C, Fisher ER, Caplan R. Relative worth of estrogen or progesterone receptor and pathologic characteristics of differentiation as indicators of prognosis in node negative breast cancer patients: findings from National Surgical Adjuvant Breast and Bowel Project Protocol B-06. J Clin Oncol 1988;6:1076-87.

12. Aaltomaa S, Lipponen P, Eskelinen M, Kosma VM, Marin S, Alhava E, et al. Hormone receptors as prognostic factors in female breast cancer. Ann Med 1991;23:643-8.

13. Lethaby AE, Mason BH, Harvey VJ, Holdaway IM. Survival of women with node negative breast cancer in the Auckland region. N Z Med J 1996;109:330-3.

14. Mostafa MG, Larsen MT, Love RR. Estrogen receptors, progesterone receptor and Her2/neu oncogene expression in breast cancers among Bangladeshi women. J Bangladesh Coll Phys Surg 2010;28:157-62.

15. Allred DC, Bustamante MA, Daniel CO, Gaskill HV, Cruz AB Jr. Immunocytochemical analysis of estrogen receptors in human breast carcinomas. Evaluation of 130 cases and review of the literature regarding concordance with biochemical assay and clinical relevance. Arch Surg 1990;125:107-13.

16. WHO. Histological typing of breast tumors, $2^{\text {nd }}$ edn, international histological classification of tumors no. 2. WHO, Geneva; 1981.

17. Story HL, Love RR, Salim R, Roberto AJ, Krieger JL, Ginsburg OM. Improving outcomes from breast cancer in a low-income country: lessons from Bangladesh. Int $\mathrm{J}$ Breast Cancer 2012;2012:423562.

18. Nadji M, Gomez-Fernadez C, Ganjel-Azad P, Morales AR. Immunohistochemistry of estrogen and progesterone receptors reconsidered: experience with 5993 breast cancer. Am J Clin Path 2005;201:1372-80.

19. Jana D, Mandal S, Mukhopadhyay M, Mitra D, Mukhopadhyay SK, Sarkar DK. Prognostic significance of HER-2/neu and survival of breast cancer patients attending a specialized breast clinic in Kolkata, Eastern India. Asian Pac J Cancer Prev 2012;13:3851-5.

20. Telli ML, Chang ET, Kurian AW, Keegan TH, McClure LA, Lichtensztajn D, et al. Asian ethnicity and breast cancer subtypes: a study from the California Cancer Registry. Breast Cancer Res Treat 2010;127:471-8.

21. Boyle P. Triple-negative breast cancer: epidemiological considerations and recommendations. Ann Oncol 2012;23(Supp1.6):vi7-12.

22. Jack RH, Davies EA, Renshaw C, Tutt A, Grocock MJ, Coupland VH, et al. Differences in breast cancer hormone receptor status in ethnic groups: a London population. Eur J Cancer 2013;49:696-702.

23. Yip CH. Breast cancer in Asia. Methods Mol Biol 2009;471:51-64.

24. Carey LA, Perou CM, Livasy CA. Race, breast cancer subtypes and survival in the Carolina Breast Cancer Study. JAMA 2006;295(21):2492-502. 